\title{
In vitro culture of Luma chequen from vegetative buds
}

\author{
Héctor Mancilla ${ }^{1}$, Karla Quiroz ${ }^{1}$, Ariel Arencibia ${ }^{1}$, Basilio Carrasco $^{2}$, and \\ Rolando García-Gonzales ${ }^{1}$ \\ ${ }^{1}$ Facultad de Ciencias Agrarias y Forestales, Universidad Católica del Maule, Campus San Miguel. Casilla \\ 617, Talca, Chile. \\ ${ }^{2}$ Facultad de Agronomía, Pontificia Universidad Católica de Chile. Ave. Vicuña Mackenna 4860, Macul, \\ Santiago, Chile.
}

\begin{abstract}
H. Mancilla, K. Quiroz, A. Arencibia, B. Carrasco, and R. García-Gonzales. 2013. In vitro culture of Luma chequen from vegetative buds. Cien. Inv. Agr. 40(3): 609-615. Luma chequen, a small tree or large shrub belonging to the Myrtaceae family, is endemic to South America and has medicinal, nutritional and ornamental potential. However, its native habitat is deteriorating gradually, and it is suffering from the effects of fragmentation that is being caused by the conversion of forest land to agricultural land and the natural expansion of monocultural plantations of exotic species, such as Pinus radiata. The purpose of this work is to develop an effective procedure for establishing in vitro cultures of the native Chilean species $L$. chequen. Aseptic nodal segments were evaluated after exposure to a disinfecting agent (1\% solution of sodium hypochlorite) for different lengths of time. Murashige and Skoog (MS) or Woody Plant (WPM) culture media with 6-Bencilaminopurine (BAP) or 2-isopentenil adenine (2-iP) added to a concentration of $1 \mathrm{mg} \mathrm{L}^{-1}$ were evaluated. Although no significant differences were observed between cultures with and without additives, $40.43 \%$ of the explant cultures were successfully established. Furthermore, the choice of basal medium or the addition of plant growth regulators was not found to affect the shoot formation efficiency.
\end{abstract}

Key words: Aseptic nodal segments, in vitro culture, Myrtaceae family, organogenesis.

\section{Introduction}

Luma chequen (Mol) A. Gray, also known as Chequén, white myrtle, or myrtle, is a shrub native to Chile that can reach a height of $9 \mathrm{~m}$. The distribution range of this species extends from Coquimbo in the Coquimbo Region to

Received May 31, 2013. Accepted October 21, 2013. Corresponding author: rgarciag@ucm.cl
Llanquihue in the Los Lagos Region. This species from the Myrtaceae family inhabits both the Hualve, which is a swampy or boggy forest, and the $\tilde{N} a d i s$, which is a forest type that grows in poorly draining volcanic soils near lakes or rivers. L. chequen is associated with Juncus $s p$. L. chequen blooms from December to March; the ripening of its fruit occurs between February and April depending on latitude (Donoso, 2006). As explained by Sandoval (2000), this species has 
recalcitrant seeds that are very sensitive to the loss of moisture, so they do not tolerate being stored for longer than a few days.

Chequén is a species that has certain medicinal properties, and it is on the list of herbs considered natural medicines by the Chilean Ministry of Health. It has edible fruit like other species of its genus, which can be a source of alternative income for farmers.

Its natural habitat is decreasing, likely because exotic species, such as Pinus radiata, have been drying up rivers and other water sources (Donoso, 2006) and naturally expanding their planting territory. Today, biotechnology offers important options for the collection and propagation of selected individuals or entire populations. It also enables the molecular characterization, disease elimination, pathogen removal, conservation, and exchange of disease-free genetic material. In this context, the application of tissue culture technology to the preservation of plant genetic resources has evolved considerably in recent years. For a number of species, especially those of conservation concern that suffer from recalcitrance of their propagation material (seed or asexual reproduction), such propagation can be considered a valid alternative to certain ex situ conservation methods (Lambardi and De Carlo, 2003).

As has been demonstrated in several cases, plant biotechnology can be used to improve the reproduction and multiplication of native recalcitrant genotypes. Using small pieces of tissue, one can study plant growth and development (SanchezOlate et al., 2005).

This study aims to develop an effective procedure for establishing in vitro cultures of the native Chilean L. chequen, a species with excellent medicinal, nutritional and ornamental potential. To our knowledge, there are no other documented studies of this type. Thus, this work could be the basis for future micropropagation protocols for $L$. chequen.

\section{Materials and methods}

\section{Plant material}

To introduce and establish L. chequen in in vitro culture, young shoots were selected during their growing season from plants growing in the nursery of the Catholic University of Maule (UTM, Zone 19 South, Ellipsoid/WGS 84 Datum: X: 263 838 - Y: 6074177). The selected shoots were $5 \mathrm{~cm}$ in length and were segmented, forming either binodal or uninodal explants.

\section{Evaluation of different disinfection procedures on plant tissue}

To introduce and establish L. chequen, the young shoots of selected explants were segmented into sections that were between 1.5 and $2.0 \mathrm{~cm}$ in length.

These explants were washed for 15 minutes with a disinfecting solution (i.e., $200 \mu \mathrm{L}$ of Tween in $3 \mathrm{~L}$ of distilled water). Subsequently, they were washed five times with distilled water to remove any residual detergent. Then, the explants were moved to a laminar flow cabinet, where the rest of the disinfection procedure was completed. Next, the explants were disinfected with a $1 \%$ sodium hypochlorite solution in two separate steps (Table 1). The explants were rinsed three times with sterile distilled water between these two steps. Finally, the explants were washed with sterile distilled water to completely remove any residual sodium hypochlorite and dried on sterile filter paper. The disinfected explants were planted in MS basal medium (salts and vitamins) (Murashige and Skoog, 1962) supplemented with sucrose (30 g $\left.\mathrm{L}^{-1}\right)$ and 6-benzylaminopurine (BAP) $\left(2 \mathrm{mg} \mathrm{L}^{-1}\right)$.

The $\mathrm{pH}$ of the media was adjusted to between 5.7 and 5.8, and it then was autoclaved for 20 minutes at a pressure and temperature of $1 \mathrm{~kg}$ $\mathrm{cm}^{-2}$ and $121^{\circ} \mathrm{C}$, respectively. The explants were maintained for four weeks under a photoperiod regime that consisted of a cycle of 12 hours of light 
Table 1. Washing times for stages 1 and 2. During each stage, the explants were disinfected with a $1 \%$ sodium hypochlorite solution. After each stage, the explants were washed three times with distilled sterile water.

\begin{tabular}{llll}
\hline \multirow{2}{*}{$\begin{array}{l}\text { Stage 1 } \\
\text { Disinfection } \\
\text { time (min) }\end{array}$} & \multicolumn{3}{c}{ Stage 2 Disinfection time (min) } \\
\cline { 2 - 4 } 20 & 20 & 30 & 40 \\
\hline 30 & T1 & T2 & T3 \\
40 & T4 & T5 & T6 \\
\hline
\end{tabular}

(light intensity $=60 \mu \mathrm{mol} \mathrm{m}^{-2} \mathrm{~s}^{-1}$ ) and 12 hours of darkness. The temperature was held at $25 \pm 1^{\circ} \mathrm{C}$.

For each treatment, the number of contaminated explants was determined. The number of explants showing budding and the extent of oxidation of the plant material were also investigated.

Each treatment was replicated two times with 10 replicates for each nodal segment. The homogeneity of variance was assessed using Levene's test, and the normality assumption was verified using the Kolmogorov-Smirnov test with a 95\% confidence interval.

The processing and analysis were performed using a one-way ANOVA and the Tukey's HDS multiple range test $(\mathrm{P} \leq 0.05)$. The statistical program, Statistical Package for Social Sciences (SPSS), was also used. The explants receiving each treatment were randomly distributed in the growing room.

Evaluation of the type of culture media and the addition of growth regulators on establishing nodal segments

After selecting the best disinfection procedure, the effect of the type of culture medium on the in vitro establishment of $L$. chequen was evaluated. The MS medium (Murashige and Skoog, 1962) and the half-strength Woody Plant Medium (WPM) (Lloyd and McCown, 1981) were evaluated. Additionally, the effect of the addition of growth regulators (cytokinine type) was evaluated by adding BAP or 2-isopentenyladenine (2-iP) to a concentration of $1 \mathrm{mg} \mathrm{L}^{-1}$ into each of these media (Table 2). All evaluated media were supplemented with sucrose $\left(30 \mathrm{~g} \mathrm{~L}^{-1}\right)$ and agar $\left(7.5 \mathrm{~g} \mathrm{~L}^{-1}\right)$. The $\mathrm{pH}$ of each media was adjusted to between 5.6 and 5.7, and it was autoclaved for 20 minutes at a pressure and temperature of $1 \mathrm{~kg} \mathrm{~cm}^{-2}$ and 121 ${ }^{\circ} \mathrm{C}$, respectively.

Table 2. Different combinations of basal media (MS (Murashige and Skoog, 1962) or WPM (Woody Plant Medium ) (Lloyd and McCown, 1981)) and plant growth regulators (BAP (6- Bencilaminopurine) or 2-iP (2isopentenil adenine)) used for inducing shoot emission of L. chequen nodal explants under in vitro culture.

\begin{tabular}{lccc}
\hline & \multicolumn{3}{c}{ Plant growth regulator } \\
\cline { 2 - 4 } Basal medium & $0\left(\mathrm{mg} \mathrm{L}^{-1}\right)$ & BAP $\left(1 \mathrm{mg} \mathrm{L}^{-1}\right)$ & $2-\mathrm{iP}\left(1 \mathrm{mg} \mathrm{L}^{-1}\right)$ \\
\hline MS & $\mathrm{T} 1$ & $\mathrm{~T} 2$ & $\mathrm{~T} 3$ \\
WPM & $\mathrm{T} 4$ & $\mathrm{~T} 5$ & $\mathrm{~T} 6$ \\
\hline
\end{tabular}

After four weeks of treatment, the extent of oxidation of the explants, the extent of bud sprouting and the average number of shoots per explant were evaluated.

Each treatment was replicated three times with six explants per replication. A test was composed of six treatments with 18 explants per treatment. Processing and analysis were performed using a factorial ANOVA and the Tukey's HDS multiple range test $(\mathrm{P} \leq 0.05)$.

\section{Results and discussion}

Evaluation of the surface disinfection of the explants

Of the total number of explants introduced, we found that $50 \%$ of the plant material was contaminated. This value is lower than that obtained by Moraga and Cifuentes (2004) in their studies of the propagation of the Chilean Myrtaceae Legrandia concinna (Phil) Kausel; 81\% of those explants were contaminated. Similarly, we were able to obtain a higher percentage of superficially 
aseptic explants than Suarez et al. (2006), who obtained only $10 \%$ aseptic explants. However, statistically significant differences in contamination levels were not observed for any of the treatment regimes that were performed. Visual inspection of the explants generally confirmed low levels of contamination, but treatment T7 exhibited the highest level of contamination. Explants were predominantly contaminated by fungi. Fewer explants were contaminated using treatment $\mathrm{T} 1$; these explants revealed morphogenic activity in lateral buds.

We found that fungi were most often present during the introduction stage of the plant material, which is consistent with the observations made by Moraga and Cifuentes (2004), Escandon et al. (2003) and Borges et al. (2009). These researchers also found that fungi were the predominant contaminants discovered during the disinfection stage of the plant material.

For those explants undergoing treatment T1, we found that more than half showed a morphogenic response. Although they exhibited a higher response of meristematic tissue, which was the most oxidized, this factor did not limit development (Figure 1). This result may have to do with the fact that young plant tissue, which has a higher resistance to stress and is less prone to oxidation, was used (Bassan et al., 2006).
Other authors note that the establishment of woody tissue in vitro is strongly affected by the oxidation of the explants (Azofeifa, 2009), especially in species of the family Myrtaceae (Picolotto et al., 2007).

\section{Evaluation of the culture media and the addition of growth regulators}

Statistical analysis was performed using the Kruskal-Wallis test. No statistically significant differences in the morphogenic response variables and the oxidation levels of the explants were found; when different growing media or growth regulators were used. Likewise, the number of average shoots per explant was not changed by the choice of culture media or growth regulator or any interaction between them. Shoot induction ranged from 10 shoots per explant when the explants were cultivated in MS without plant growth regulators to 18 shoots per explant when they were planted in WPM supplemented with $1 \mathrm{mg} \mathrm{L}^{-1}$ of 2-iP.

Furthermore, we observed improved qualitative development (greater length of regenerated shoots) for explants established in WPM culture medium supplemented with 2-iP. In woody species introduced to in vitro cultivation, the addition of growth regulators was needed to stimulate the
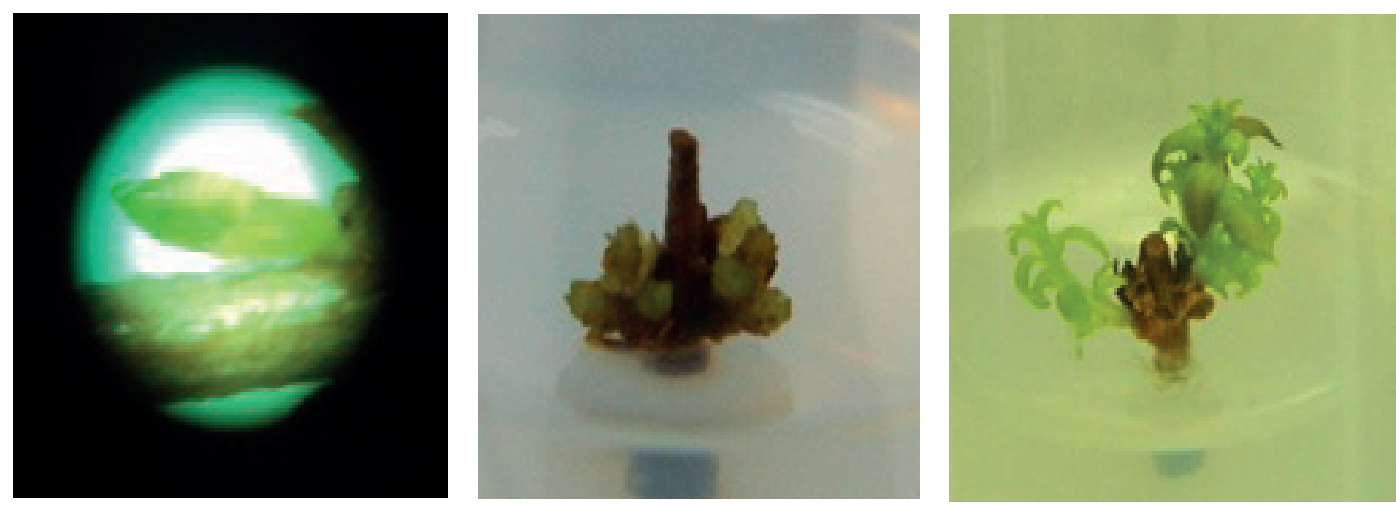

Figure 1. Shooting of $L$. chequen explants in in vitro culture. A) Disinfected buds before establishment in vitro. Morphogenic development of in vitro nodal explants of $L$. chequen after two (B) and six (C) weeks of treatment. 
development of high-quality morphogenic tissue (Gomes et al., 2010; Cob et al., 2010; Brondani et al., 2009; Sanchez-Olate et al., 2004). The culture medium used in this study had no major influence on tissue development. However, visual inspections showed that the release of phenolics was enhanced when explants were cultured in MS, which is possibly due to the higher concentration of salt in this medium versus the WPM culture medium. Tetsumura et al. (2008), Mereti et al. (2002) and Andreu and Marin (2005) found that the efficiency of the morphogenic response of plants in different culture media was dependent on the genotype of the species used, the concentration of salts present in the culture medium, and the species itself.

According to our results, the establishment of L. chequen may be performed in vitro from field explants harvested during its growing season. The propagation can be performed by washing the explants two times with $1 \%$ sodium hypochlorite for 20 minutes each time and then incubating the plant material in WPM. It is not necessary to add growth regulators to the media (Figure 2).
This is the first time that $L$. chequen has been propagated in in vitro conditions, and this technology will open up the possibility for the sustainable use of this species. The disinfection method used herein enabled the establishment of explants of $L$. chequen that were free of surface or endogenous contaminants from actively growing young shoots. In addition, this study established an efficient culture medium that could be used to induce shooting in disinfected explants and found that the type of cytokinine incorporated into the culture medium did not significantly affect the efficiency of shooting. We recommend the application of this disinfection protocol for further studies investigating the in vitro establishment of $L$. chequen and other Chilean species of the Myrtaceae family.

\section{Acknowledgments}

The authors would like to thank the Fondo de Innovación para la Competitividad (FIC-R) from the Región del Maule for partially supporting this research under project BIP 3303689-0. We would also like to express our gratitude to Mr. Juan Carlos Bobadilla for kindly providing access to the plant material.
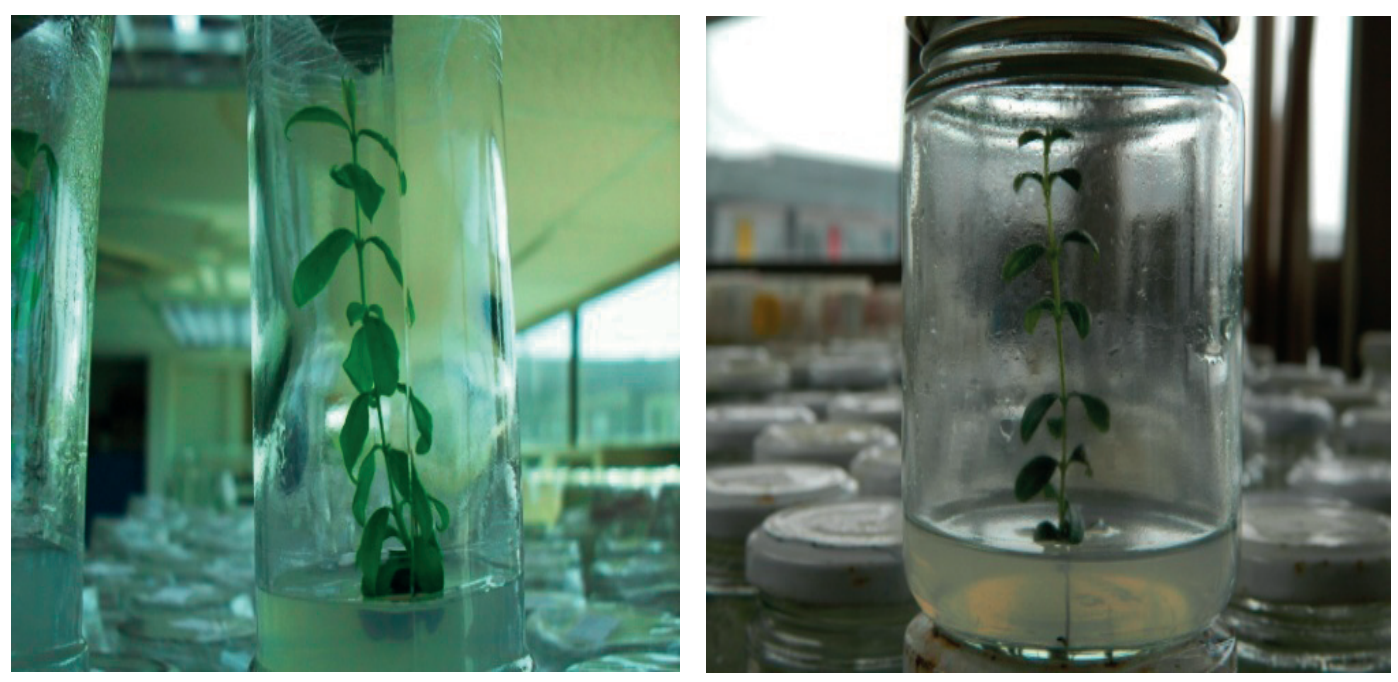

Figure 2. In vitro plantlets of Luma chequen established from nodal explants after four months and four propagation cycles (four weeks each) in Woody Plant Medium supplemented with $1 \mathrm{mg} \mathrm{L}^{-1}$ of 2-iP. 


\section{Resumen}

H. Mancilla, K. Quiroz, A. Arencibia, B. Carrasco y R. García-Gonzales. 2013. Establecimiento al cultivo in vitro de Luma chequen a partir de segmentos nodales. Cien. Inv. Agr. 40(3): 609-615. Luma chequen pertenece a la familia Myrtaceae y es una especie endémica de Sudamérica. Su hábitat se está deteriorando paulatinamente producto de la conversión de suelos forestales a suelos agrícolas y por las plantaciones en monocultivo con especies exóticas, como Pinus radiata. Por otro lado, la regeneración natural de la especie es escasa, debido a la escasa viabilidad de sus semillas en sus hábitats originales. El presente trabajo tiene por objetivo desarrollar un procedimiento eficaz de establecimiento al cultivo in vitro para la especie nativa chilena Luma chequen, la que se tiene un alto potencial para uso medicinal y en la industria de los nutracéuticos. Para el establecimiento al cultivo in vitro de segmentos nodales se evaluó el efecto del tiempo de exposición de los explantes ante el hipoclorito de sodio (1\%), la composición del medio de cultivo y el tipo de regulador del crecimiento (BAP y 2-iP a $\left.1 \mathrm{mg} \mathrm{L}^{-1}\right)$. Se obtuvo un 40,43\% de eficiencia en el establecimiento de los explantes. No se observó un efecto significativo de los medios de cultivo o los reguladores del crecimiento sobre la emisión de brotes en los explantes establecidos.

Palabras clave: Cultivo in vitro, establecimiento, familia Myrtaceae, organogénesis, segmentos nodales asépticos.

\section{References}

Andreu, P., and J. Marín. 2005. In vitro culture establishment and multiplication of the Prunus rootstock 'Adesoto 101' (P. insititia L.) as affected by the type of propagation of the donor plant and by the culture medium composition. Scientia Horticulturae 106:258-567.

Azofeifa, Á. 2009. Problemas de oxidación y oscurecimiento de explantes cultivados in vitro. Agronomía Mesoamericana 20:153-175.

Bassan, J., L. Reiniger, B. Rocha, C. Severo, and A. Flôres. 2006. Oxidaçao fenólica, tipo de explante e meios de cultura no estabelecimento in vitro de Canafístula (Peltophorum dubium (Spreng.) Taub.). Ciência Florestal 16:381-390.

Borges, G., A. Estrada, R. Pérez, and R. Meneses. 2009. Uso de distintos tratamientos de desinfección en el cultivo in vitro de Dioscorea alata L. clon caraqueño. Revista Colombiana de Biotecnología 11:127-135.

Brondani, G., L. Dutra, F. Grossi, I. Wendling, and J. Hornig. 2009. Estabelecimento, multiplicação e alongamento in vitro de Eucalyptus benthamii Maiden \& Cambage x Eucalyptus dunnii Maiden. R. Árbore 33:11-19.

Cob, J., A. Sabja, D. Ríos, A. Lara, P. Donoso, L. Arias, and B. Escobar. 2010. Potencial de la organogénesis como estrategia para la masificación in vitro de Persea lingue en la zona centro-sur de Chile. Bosque 31:202-208.

Donoso, C. 2006. Especies Arborescentes. In: C. Donoso (ed.). Las especies arbóreas de los bosques templados de Chile y Argentina. Autoecología. Marisa Cuneo, Valdivia, Chile. p. 590.

Escandón, A. S., P. Ferrari, G. Facciuto, S. Soto, J. C. Hagiwara, and A. Acevedo. 2003. Combinación de técnicas in vitro y ex vitro para la micropropagación de santa (Hibr.) una arbustiva de relevancia ornamental. RIA. Revista de Investigaciones Agropecuarias 32:111-122.

Gomes, G., R. Paiva, R. Herrera, and P. Paiva. 2010. Micropropagation of Maclura tinctoria L.: an endangered woody species. Revista Árvore 34:25-30.

Lambardi, M., and A. De Carlo. 2003. Application of tissue culture to the germoplasm conservation of 
temperate broad - leaf trees. In: S. Mohan, and I. Katsuaki (eds.). Micropropagation of Woody Trees and Fruits. Kluwer academic publishers, Dordrecht, Netherlands. p. 817.

Lloyd, G., and B. McCown. 1981. Commercially feasible micropropagation of mountain laurel, Kalmia latifolia, by use of shoot tip culture. Proc. Int. Plant Propag. Soc. 30:421-427.

Mereti, M., K. Grigoriadou, and G. Nanos. 2002. Micropropagation of the strawberry tree Arbutus unedo L. Scientia Horticulturae 93:143-148.

Moraga, M. and L. Cifuentes. 2004. Aplicación de técnicas de cultivo in vitro en la propagación de Legrandia concinna. Bosque 25:129-135.

Murashige, T. and Skoog, F. 1962. A revised medium for a rapid growth and bioassays with tobacco tissues cultures. Plant Physiol. 15:473-479.

Picolotto, L., M. Schuch, J. Souza, L. Silva, J. Ferri, and J. Fachinello. 2007. Efeito do hipoclorito de sódio, fotoperíodo e temperature no estabelecimento in vitro de Jabuticabeira. Scientia Agraria 8:19-23.

Sanchez-Olate, M., D. Ríos, M. Pedraza, G. Pereira, H. Castellanos, and R. Escobar. 2004. Propagación in vitro de Nothofagus procera ((Poepp. et Endl.) Oerst.) a partir de embriones aislados. Bosque 25:123-128.

Sánchez-Olate, M., D. Ríos, and R. Escobar. 2005. La biotecnología vegetal y el mejoramiento genético de especies leñosas de interés forestal y sus proyecciones en Chile. In: E. Sánchez-Olate, and D. Ríos (eds.). Biotecnología vegetal en especies leñosas de interés forestal. Universidad de Concepción. Concepción, Chile. p. 17.

Sandoval, S. 2000. Centro de Semillas y Árboles Forestales. Facultad de Ciencias Forestales, Universidad de Chile. Available online at: http:// www.cesaf.uchile.cl/cesaf/n14/1.html (Website accessed: June 2, 2010).

Suárez, I., A. Jarma, and M. Avila. 2006. Desarrollo de un protocolo para propagación in vitro de roble (Tabebuia rosea Bertol DC). Temas Agrarios 11:52-62.

Tetsumura, T., Y. Matsumoto, M. Sato, C. Honsho, K. Yamashita, H. Komatsu, Y. Sugimoto, and H. Kunitake. 2008. Evaluation of basal media for micropropagation of four highbush blueberry cultivars. Scientia Horticulturae 119:72 - 74. 
